\title{
Factors Affecting Employee Satisfaction of the Public and Private Sector Organizations of Pakistan
}

\author{
Ayesha Masood \\ Department of Management Sciences, The Islamia University of Bahawalpur, Pakistan \\ E-mail: Ayesha.masood106@hotmail.com
}

Qurat-Ul-Ain

Department of Management Sciences, The Islamia University of Bahawalpur, Pakistan

E-mail: Annie_4576@yahoo.com

\begin{abstract}
Rabia Aslam
Department of Management Sciences, The Islamia University of Bahawalpur, Pakistan

E-mail: Rafiaaslam15@hotmail.com
\end{abstract}

Muhammad Rizwan

Lecturer, Department of Management Sciences

The Islamia University of Bahawalpur, Pakistan

Email: rizwan.arshad@iub.edu.pk

Doi:10.5296/ ijhrs.v4i2.5902 URL: http://dx.doi.org/10.5296/ ijhrs.v4i2.5902

\begin{abstract}
The purpose of this study is to find out the factors that affect employee satisfaction and how much is the intensity. Specifically, we took Working conditions, pay \& promotion, Job safety and security, Training and development and employee empowerment as the antecedents to see their impact on employee satisfaction and further the impact of employee satisfaction on Job performance and employee turnover intention. This can help us to better understand about the satisfaction level of employees and how we can motivate employees to perform their job efficiently and effectively. The Sample was collected from different organizations of Bahawalpur City (Punjab, Pakistan). Two main clusters were targeted to collect the sample data university employees and some private organizations in the city. The questionnaire was distributed among 200 respondents in Bahawalpur City. 155 questionnaires were selected and
\end{abstract}


rests of the questionnaires were not included in the further analysis due to incomplete or invalid responses. The survey study addresses two major purposes; first is to analyze the relationship of different variables with employee satisfaction, second to collect information about the different characteristics. After collecting the completed questionnaires, these questionnaires were coded and entered into SPSS sheet and the hypothesis was tested using regression analysis. Result of our study show significant relationship of working conditions, Job Safety and security, Training and Development and Employee Empowerment on Employee Satisfaction and Job Performance. However, Pay and promotion has no significant relation with Job Performance. Employee Satisfaction has a significant negative relation with turnover intention.

Keywords: Working Conditions, Pay and Promotion, Job Safety and Security, Training and Development and Employee Empowerment

\section{Introduction}

One of the most integral parts of routine life is Job life. The way in which employee think, feel and perceive their jobs is to be known as Job Satisfaction. Most scholars and researchers found various methods to attain Job satisfaction in any of the workplace that is now used by Human resource managers in order to motivate, attract and retain their workforce.

Job satisfaction and Organizational commitment are some of the attitudes that mainly influence the HRM practices. Absenteeism, commitment, performance and productivity directly influence the level of job satisfaction. Moreover, job satisfaction improves the retention level of employees and minimizes the expense of hiring fresh employees.

Many of the determinants have been explored to understand the job satisfaction such as management role, work motivation, pay, other benefits, organizational environment, and employee learning perception. This research explored the relationship status between Job Satisfaction level of employees of public and private sector that as a result help to have Influential and smooth management system in the Organization.

Job satisfaction describes a collection of factors that creates a feeling of satisfaction. It can be simply stated as a combination of how an individual feel, thinks and perceive about his or her Job and it is affected by many internal and external factors. A set of positive and negative feelings that an employee have about his job is known as job satisfaction. When an organization really comes up to the expectations what an employee really needs from his job, it means that the organization is working towards the Employee satisfaction and understand its importance. The stage where the actual benefits meets the expectations it means employee satisfaction level is rising up. The behavior that an individual has at workplace describes the employee satisfaction in a well manner. Training could be an important factor that helps in increasing the satisfaction of employee, as it acknowledges the person about his or her jobs and provides a better understanding. Training equipped employees with certain skills that are required for the enhanced performance regarding job responsibilities. So as training provides necessary skills indirectly improves the satisfaction and so as performance as well. 
Job performance can be stated as the way people perform their jobs. Job performance is a term that is widely used in almost every small and big organization but it is still not clearly defined. During the job performance review session an employee`s performance is measured and management is much more concerned about job performance of their employee finding ways to improve it.

The management method that has instruments such as motivation, job enrichment, communication, trust, participative Management, delegation, training and feedback is all closely related to employee empowerment that is essential to observe managerial aspects from various prospective. Employee empowerment brings up a relation between the work performed and the job satisfaction the employees will get through it and it is also a widespread activity, and the technique that empowerment activities are practiced now in most of the organizations and workplace according to the culture and norms. One of the important dimensions of employee empowerment, Behavioral empowerment, creates an tools and motivates convenient communications to drive a positive effect in creating job satisfaction. Psychological empowerment is another dimension of employee empowerment that tells that how an employee feel about his position and authority in making decisions, giving orders to subordinates and regulating task activities in the organization that makes him feel satisfied and strong. Results of many researches justifies that there is a significant relationship between the both empowerment tool and the job satisfaction concept and it drives a person to attain the satisfaction he needed from his job. So when both empowerments are entirely implemented in the organization it helps to attain satisfaction that is required to run the operations smoothly, effectively and efficiently.

Moreover, Job satisfaction is the result of many other factors such good working Conditions, an appropriate pay and promotion systems, properly defined job safety and security to employees, Training and empowerment given to employees. So all this comes together and creates job satisfaction and any one`s absence could greatly affects the satisfaction level.

The General Purpose of our research is to know about the factors that affect the satisfaction level of an employee in an organization and up to what extent they influence the satisfaction of employees. Specifically, we took Working conditions, Pay and Promotion, Job Safety and Security, Job training and Development and Employee Empowerment as the antecedents to see their effect on the satisfaction level of employees, Job performance and consequently their effect on employee turnover intention.

Working Condition is strongly associated with employee satisfaction and has a significant impact on it. Pay and promotion plays vital role in satisfying or dissatisfying an employee. An employee satisfaction is highly based on the safety and security of the Job; employees are more committed and satisfied with a secure job than any other thing. Job training is significantly and positively associated with employee satisfaction, as employees are more educated about their jobs their performance enhances and so their satisfaction. Empowerment involves giving employees the autonomy to make decisions they go about their daily activities so empowerment enhances the motivation of employees to go through their goals grooming their performances that increases their satisfaction regarding their Jobs 


\section{Literature Review}

\section{Employee Satisfaction}

Job satisfaction refers to the people's feelings about the benefits they have received on the job.

Employee satisfaction as simply how people feel about their jobs and various aspects of their jobs suggested by Lawler (1990). Some definitions tell about a discriminated attitude in which job satisfaction is seen as consisting of satisfaction with various dimensions of the job and the work situation. By totaling the satisfaction identified for many various dimensions of the job and the work situation, in this approach job satisfaction is measured. This type of assessment gives an exact picture of the employee's total job satisfaction. Hence, in our study, we measured job satisfaction using numerous aspects of the job and the work situation. According to Locke, ( 1976) job satisfaction as pleasurable emotional state resulting from appraisal of one's job or job experience (According to Rainey (1997), job satisfaction is most frequently studied variable in organizational research that is significant that what kind of feeling people have about their job and different features of their job. This is a exact and best way to know about people liking or disliking of their job (Spector, 1997) Rainey (1997) said that on studying employee fulfillment the satisfaction of employees is extensively read out inconsistent in managerial background, that is right that how individuals think about their workplace or job and different aspects of the job. Employee satisfaction as an enjoyable or positive emotional state resulting from the appraisal of one's job or job experience Locke (1976). Rice et al. (1989) proposed that "satisfaction is determined, in part, by the discrepancies resulting from a psychological comparison process involving the appraisal of current job experiences against some personal standards of comparison."Employee satisfaction is a significant variable that is able to give estimation about general emotion and thinking forms of employees about their job and workplace. Thus, employee satisfaction related to hopes of the employee about the workplace and his approaches forward his job. Job satisfaction is a function of the extent to which one's needs are satisfied in a job (Togia et al., 2004).

\section{Job Performance}

According to Porter and Lawler (1968), there are three types of performance. First is the evaluation of output rates, amount of sales over a given period of time, the production of a group of employees reporting to manager, and so on. The second type of performance evaluation considers ratings of individuals by someone other than the person whose performance is being considered. The third type of performance measures is self-appraisal and self-ratings. As a result, the acceptance of self-appraisal and self-rating techniques are useful in promising employees to take an active role in setting his or her own goals. According to (Hersey and Blanchard, 1993) basically job performance measure the level of success of business and social aims and responsibilities from the perspective of the judging party

It is an unclear concept that is used in different organizations (the branch of psychology that 
deals with the workplace). It is also a part of Human Resource Management. Goris, Vaught and Pettit (2003) were among those who performed research on this subject and took it into the renown to solve the problems. It mostly used to judge a person performs their job well or not. An employee's performance is determined during job performance reviews.

(Currall et al., 2005) saysthere is demand of very skilled, skilled and qualified employees in the labor market. The output and production of an organization is measured in terms the performance of its workforce. To know about level of job satisfaction better performance of workforce is a good way (Sousa-Poza and Sousa- Poza, 2000). Nanda and Brown (1977) explored the important employee performance pointers at the hiring stage. We resulted that level of job satisfaction and motivation affects the employee's efficiency. And now it becomes predicament for the human resource experts to keep the performer (Sumita, 2004).(Meyer, 1999) proposes that the low level of job satisfaction badly effects on the employee commitment and successively effect the achievement of organizational objectives and performance.

H2: The job satisfaction has positive impact on employee performance.

\section{Working Condition}

(Herzberg, 1968; Spector, 2008) states Work environment is an significant factor of job satisfaction of employees that work environment, in the new research, was found to be better factorof job satisfactions by the scholars (Reiner and Zhao,1999; Carlan, 2007; Ellickson and Logsdon, 2001; Forsyth and Copes, 1994).

Ceylan said in 1998 working conditions have features about the job such as calm and easy workplace, drying, lighting and temperature, bigger, better and cleaner work spaces, and office spaces. These factors have impact on worker job satisfaction. When this is provided by the firm, employee satisfaction raises. Some studies tell that low job-satisfaction levels can be mostly attributed to the physical working conditions (De Troyer, 2000)

Employee performs their duties and daily activities in workplace environment. Commonly noise level, fresh air, and the incentives e.g. child care, also become a part of work environment. Workplace surroundings may have positive or negative impact on the satisfaction level of employee's subject upon the nature of working environment. Employees do well in a calm working environment. Hence working conditions have a positive and strong effect on employee satisfaction.

H3: There is a positive and strong relationship between working conditions and employee satisfaction. 


\section{Pay and Promotion}

The level of satisfaction is discriminatory with the level of pay and benefits and promotion system. Pay is a very vital feature. There is positive connection between equity based on compensation and performance Frye (2004). It was determined that the income is the major factors of job satisfaction, the study regarding job satisfaction level of public sector mangers was conducted and (Sokoya, 2000). The investigation conducted about relationship among job satisfaction and pay it was also found that job satisfaction is affected by the pay (Nguyen et al., 2003).

(Hill \& Wiens-Tuers 2002). Survey results of Kathawala, Moore and Elmuti (1990) tell that the salary package is the only factor that enhances the motivational and satisfaction level of salaried employees in an automobile sector. It is important to note that reward or compensation) is a very important tool to control employee turnover. It also encourages the organizational commitment of the employee, which in turn attract besides the employee with the job (Zobal, 1998; Chiu et al., 2002; Moncarz et al., 2009). , the wages of the co-worker are more important for an employee(Cappelli and Sherer 1988, Clark and Oswald1996, Brown et al 2008, and others). Hammermesh (2001) found that the increase in earning shocks has temporary effects on employee job satisfaction.

H4: Pay \& Promotion has a positive impact on employee satisfaction.

\section{Job Safety and Security}

Job dissatisfaction is the result of uncertainty among employees (Ashford et al., 1989; Davy et al., 1991). Abegglen (1958) found during the study of Japanese workers that job security leads to high commitment in employee arrangement like lifetime employment and seniority system. Bolt (1983), Mooney (1984), Rosowand Zager (1985) concluded that due to insecurity of job the job performance decreases.

Iverson (1996) appealed that job security has momentous effect on the organizational pledge. Morris et al. (1993) resulted the same. It was found that job performance and organizational assurance are destructively connected with job insecurity (Rosenblatt and Ruvio, 1996).

H5: Job safety and security has positive impact on job satisfaction.

\section{Job Training and Development}

To the increase in quality of their performance, training is the process of civilizing the skills, skills and knowledge of people which moulds their thinking and hints. We can say that it is a constant process of deep concern for most of the studies. Training is vital and fertile for both employee and organizational improvement. To achieve individual development Employee training provides prospects to employees broaden their knowledge and capacities for more 
well-organized teamwork (Jun et al., 2006). According to (Saks, 1996)when workers receive self-growth training, the level of their job satisfaction is advanced than those without such training also, Martensen and Gronholdt (2001) found that the development of individual competencies through various training programs has a positive impact on employee satisfaction. When employees attended to training programs, they achieve self-confidence of making their jobs, they observe career development opportunities and they think that their companies make investment in them (Jun et al., 2006). As result of this positive situations, employee satisfaction increases. Many authors claim that job training is an important predictor of employee positive attitudes (Shields and Wheatley,2002; Schmidt, 2007a, b). It is a set of planned activities on the part of an organization to increase the job knowledge and skills of its members in a manner consistent with the goals of organization (Landy, 1985). Georgellis and Lange (2007) states that the proper accessibility of written materials for learning, courses, participation in seminars and conferences for the employees is to be known as Job training. Another research in UK, Jones et al. (2008) and Gazioglu and Tinsel (2006) emphasize the positive part of job training on employee job satisfaction. Blum and Kaplan (2000) have also identified that chance to learn new skills and the job satisfaction is positively associated with each other.

H6. Employee job Training has positive impact with employee job satisfaction.

\section{Employee Empowerment}

(Carless, 2004; Haas, 2010) suggested that Employee empowerment refers to the authority endorsed to employees in decision-making in routine activities

Hales and Klidas (1998) state when you share your authority and power with your underlings you are practicing empowerment. Empowerment is a construct associated to the employee`s confidence on their selves and the motivation and inspiration to work Conger and Kanungo (1988). (Silva, HUTCHESON and WAHL, 2010) tells us that Employee's commitment reaction is strongly related with the employee empowerment. Employee's abilities and qualification matters and it really depends on the Job for which the employee is being hired, if answer is positive then the employee would effort passionately and would have better sense of belongingness to the firm. Employee Empowerment is a way to improve the employee satisfaction. Wrong hiring for the organization could impact the productivity negatively and could increase turnover percentage, employees will be more willing to leave the organization sooner, and giving them a sense of empowerment can raise their motivations and performance. Job satisfaction and perceived service quality is strongly positively associated with the employee empowerment. Different researches has highlighted and revealed a positive link between the psychological empowerment and the job satisfaction suggested by (Aryee and Chen, 2006; Kuo et al., 2007; Sahin, 2007; Spreitzer et al., 1997; Wang and Lee, 2009). Job satisfaction level is positively and significantly influenced by the tools used by the management such as smooth and appropriate communications, Behavioral empowerment, a 
relation and environment of belief on others. Managers can utilize all these or one of them to create an atmosphere of satisfaction for the employees said by (Babin and Boles, 1996; Yoon et al., 2001; Younas et al., 2013). The decision-makers and the workers get closer to each other by the applying the empowerment and this reduces the time taken to complete the task activities. Managers can help employees develop a sense of self-confidence that can lead to the employee empowerment

H7: Empowerment has positive impact on Employee Satisfaction.

\section{Turnover Intention}

(Mobley, 1977) states Turnover intention in his words as a desire or intention to leave the job voluntarily. Moreover, it can be described as switching the job intentionally or overall leaving the labor market. A thoughtful intention and willfulness to switch the organization is considered as Turnover intention suggested by (Tett and Meyer, 1993). Leaving the department or organization at own desire is known as turnover intention (Tett \& Meyer, 1993). Whenever the satisfaction level of an employee is raised it depicts a strong negative relationship with the turnover intention construct argued by (Muchinsky \& Morrow,1980; Trevor, 2001; Rizwan et al., 2013).When the employee is not given what he deserves, he is not pleased with the job then there is intention of the employee to discontinue the job but when the employees are happy and satisfied with their

job then level of intentions of goodbye to the organization reduces to much extent. Job satisfaction and turnover intentions are inversely proportional concepts and it is practically tested statement. Boshoff and Allen (2000) found that employee`s willfulness to switch the organization minimizes as their performances regarding their services rising up. Performance and the intention to leave the organization are two negatively associated concepts reported by Viator (2001).Furthermore Martin (1979) showed that a sample of employees been tested upon this concept and it depicts a strong negative association between the turnover intention ad employee satisfaction. Employee satisfaction is proven to be an important predictor to find the level of switching intention of an employee argued by (Tett and Meyer (1993),

H8: Employee satisfaction has significant negative impact on turnover intention. 


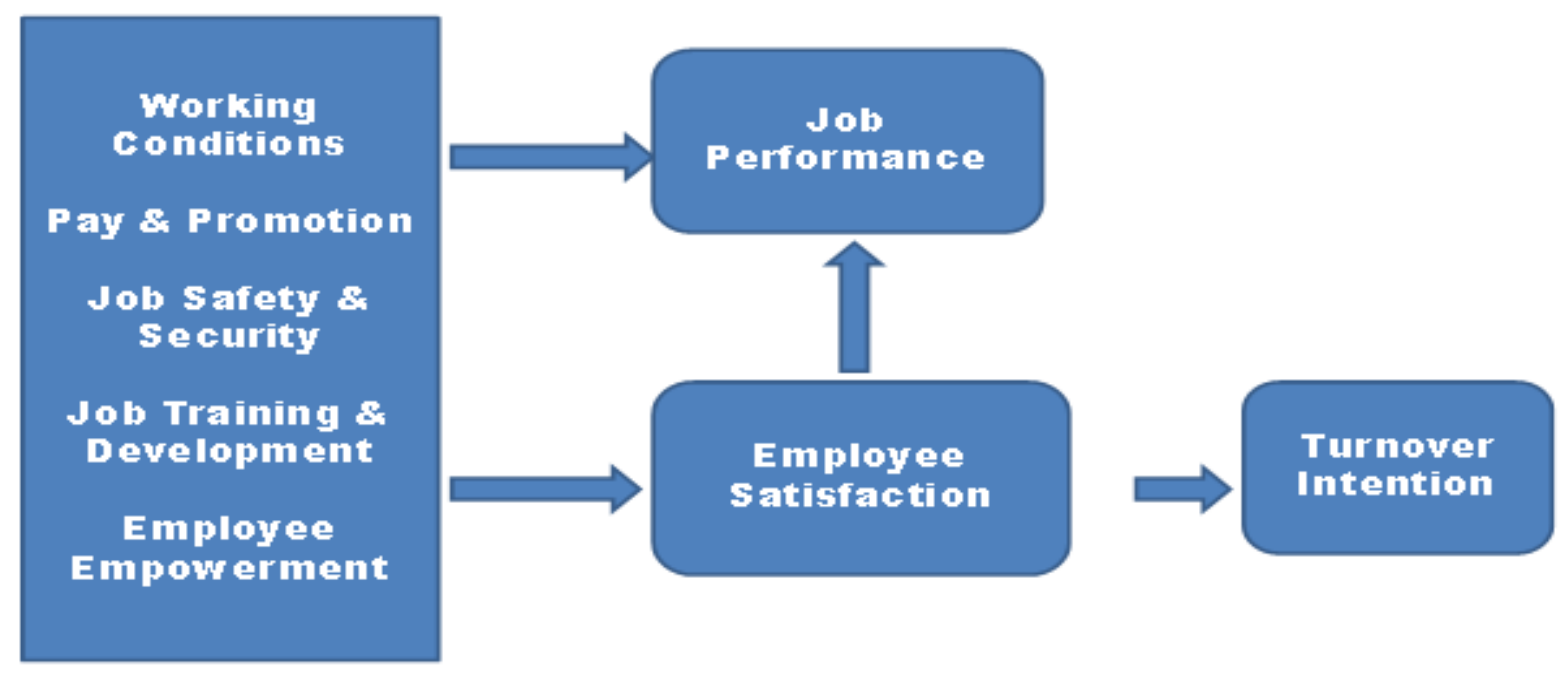

\section{Research Model}

\section{Research Methodology}

The present research is descriptive in its nature. Descriptive research can be described as relating something, some occurrence or any specific state. (Creswell, 1994) identifies descriptive researches are those researches that explains the current situation instead of deducing and making decisions. The main purpose of the descriptive study is verification of the proposed hypothesis that depicts the present situation. This kind of study delivers information about the existing scenario and emphasize on past or present for example quality of life in a community or customer attitudes in the direction of any marketing goings-on (Kumar, 2005).

\subsection{Sample Data}

In order to gather the data for understanding the antecedents impacting Employee Satisfaction, a sample of 155 respondents were asked to take part in a self-administered questionnaire. The population for the existing research is employees working in public and private sectors of Bahawalpur City. The current study utilizes a non probability sampling technique that is convenience sampling. Convenience sampling is a sampling technique that obtains and collects the relevant information from the sample or the unit of the study that are conveniently available (Zikmund, 1997). Convenience sampling is normally used for collecting a large number of completed surveys speedily and with economy (Lyme et al, 2010).

It is ensured that the sample members possess two main qualifications to participate in the self-administered survey. First, the sample members should have enough knowledge about 


\section{Macrothink}

International Journal of Human Resource Studies

ISSN 2162-3058

2014, Vol. 4, No. 2

their jobs; secondly, they have been working in any public or private sector organizations of Pakistan.

\subsection{Instruments and Measures}

The survey instrument of the existing research report two major purposes: First is to analyze the relationship of different variables affecting Employee Satisfaction. Second, to collect information about the different characteristics of the respondents that can be used to understand the variations in different categories.

The survey instrument contains two sections. Section 1 includes different personal and demographic variables. This section will obtain the respondent's information about gender, age, income and education.

Section 2 includes the hidden variables that are important in the current study. These variables include Employee satisfaction, Job Performance, Working Conditions, Pay and Promotion, Job safety and security, Training and development, Employee Empowerment and Turnover intention. This section of research is developed based on the past literature and already used questionnaires.

The scales of the study were adopted from the previous literature and published studies. The first variable of the study was Employee satisfaction having four items taken from Spector (1997). The next variable is Job Performance having three items that was taken from the study Corral et al., (2005). The next variable Working Conditions having three itemsrefers to (Herzberg, 1968; Spector, 2008). The next variable Pay and Promotion having four items refers to Frye (2004). Next Variable Job Safety and Security having five items taken from (Ashford et al., 1989; Davy et a., 1991). The sixth Variable Training and Development having five items refers to Jones et al., (2008). The next Variable Employee Empowerment having four items taken from (Hackman and Oldham, 1975). The next Variable Turnover Intention having four items refers to (Muchinsky \& Morrow, 1980; Trevor, 2001). 
TABLE 1: SCALES OF THE STUDY

\begin{tabular}{|c|c|c|c|}
\hline No & Variable & Items & Reference \\
\hline 1. & $\begin{array}{l}\text { Employee } \\
\text { Satisfaction }\end{array}$ & $\begin{array}{l}\text { 1. My job in this organization has met my } \\
\text { expectations. } \\
\text { 2. Overall, I am pleased with my work. } \\
\text { 3. Overall, I am satisfied in my current } \\
\text { practice. } \\
\text { 4. My current work situation is not a major } \\
\text { source of frustration in my life. }\end{array}$ & $\begin{array}{l}\text { Conrad et al. } \\
\text { (1999). }\end{array}$ \\
\hline 2. & $\begin{array}{l}\text { Job } \\
\text { Performance }\end{array}$ & $\begin{array}{l}\text { 1. My performance is better than that of my } \\
\text { colleagues with similar qualifications. } \\
\text { 2. I am satisfied with my performance } \\
\text { because it is mostly good. } \\
\text { 3. My performance is better than that of } \\
\text { other employees with similar } \\
\text { qualifications in other Organizations. }\end{array}$ & Boraet al., 2011). \\
\hline 3. & $\begin{array}{l}\text { Working } \\
\text { Conditions }\end{array}$ & $\begin{array}{l}\text { 1. My working hours are reasonable. } \\
\text { 2. I am never overworked. } \\
\text { 3. I get the opportunity to mix with my } \\
\text { colleagues and to communicate on } \\
\text { aspects of our work. }\end{array}$ & $\begin{array}{l}\text { Rosh } \\
\text { anLevinaRoberts } \\
(2005)\end{array}$ \\
\hline 4. & $\begin{array}{l}\text { Pay and } \\
\text { Promotion }\end{array}$ & $\begin{array}{l}\text { 1. I am satisfied with the existing salary } \\
\text { structure of the company. } \\
\text { 2. I am satisfied with the compensation I } \\
\text { get \& I think it matches with my } \\
\text { responsibility. } \\
\text { 3. I am often rewarded for the quality of }\end{array}$ & Hayes, 1994) \\
\hline
\end{tabular}




\begin{tabular}{|c|c|c|c|}
\hline & & $\begin{array}{l}\text { my efforts. } \\
\text { 4. I am valued by my supervisor. }\end{array}$ & \\
\hline 5. & $\begin{array}{l}\text { Job Safety and } \\
\text { Security }\end{array}$ & $\begin{array}{l}\text { 1. I am not afraid I will get fired. } \\
\text { 2. I do not worry about keeping my job. } \\
\text { 3. I have no fear that I will lose my job. } \\
\text { 4. I don't think I might get fired in the near } \\
\text { future. } \\
\text { 5. I am sure I can keep my job. }\end{array}$ & De Witte (2000). \\
\hline 6. & $\begin{array}{l}\text { Training and } \\
\text { Development }\end{array}$ & $\begin{array}{l}\text { 1. My Organization provides me the } \\
\text { opportunity to improve my skills. } \\
\text { 2. There is lot of chance to learn new } \\
\text { things in this company. } \\
\text { 3. My Organization frequently arranges } \\
\text { training programs for the employees. } \\
\text { 4. Doing job in this Organization will } \\
\text { benefit me in the future. } \\
\text { 5. I am satisfied with the training and } \\
\text { development provided by my } \\
\text { organization. }\end{array}$ & $\begin{array}{l}\text { Martensen and } \\
\text { Gronholdt (2001) }\end{array}$ \\
\hline 7. & $\begin{array}{l}\text { Employee } \\
\text { Empowerment }\end{array}$ & $\begin{array}{l}\text { 1. I have the authority to correct daily } \\
\text { problems when they occur. } \\
\text { 2. I am encouraged to handle daily } \\
\text { problems by myself. } \\
\text { 3. I have control over how I solve daily } \\
\text { problems. } \\
\text { 4. I am able to control the social contact } \\
\text { with others around. }\end{array}$ & $\begin{array}{l}\text { (Hackman and } \\
\text { Oldham, 1975) }\end{array}$ \\
\hline
\end{tabular}




\begin{tabular}{|l|l|l|l|l|}
\hline 8. & Turnover \\
intention & $\begin{array}{l}\text { 1. I often think about quitting my } \\
\text { Organization. }\end{array}$ & Bluedorn (1982) \\
2. It is likely that I will actively look for a \\
new job very soon. \\
3. I often think of changing my job. \\
4. My preference is now to be a part of \\
some other organization.
\end{tabular}

\subsection{Procedure}

The questionnaire was distributed among 155 respondents in Bahawalpur City of Pakistan. These respondents are selected based on the criteria above mentioned. Before giving the questionnaire, the purpose of the study and questions were explained to the respondents so they can easily fill the questionnaire with relevant responses. A total of 155 questionnaires selected. After collecting, the completed questionnaires were coded and entered into SPSS sheet for further analysis.

\subsection{Reliability Analysis}

\begin{tabular}{|l|l|l|}
\hline Scales & Items & Cronbach Alpha \\
\hline Employee Satisfaction & 4 & .670 \\
\hline Job Performance & 3 & .602 \\
\hline Working Conditions & 3 & .561 \\
\hline Pay and Promotion & 4 & .581 \\
\hline Job Safety and Security & 5 & .596 \\
\hline Training and Development & 5 & .792 \\
\hline Employee Empowerment & 4 & .669 \\
\hline Turnover Intention & 4 & .755 \\
\hline
\end{tabular}




\section{Macrothink \\ International Journal of Human Resource Studies \\ ISSN 2162-3058 \\ 2014, Vol. 4, No. 2}

\section{Results and Analysis}

\subsection{Profile of the Respondents}

Personal and demographic information of the respondents is presented in the following table

\begin{tabular}{|c|c|c|c|}
\hline & Category & Frequency & Percentage \\
\hline \multicolumn{4}{|l|}{ Variable } \\
\hline \multirow[t]{2}{*}{ Gender } & Male & 117 & 75.483 \\
\hline & Female & 38 & 24.516 \\
\hline \multirow[t]{6}{*}{ Age } & $15-20$ years & 1 & 6 \\
\hline & $20-25$ years & 26 & 17 \\
\hline & 25-30 years & 47 & 22.6 \\
\hline & $30-35$ years & 35 & 16.1 \\
\hline & $35-40$ years & 25 & 13.5 \\
\hline & Above 40 years & 21 & \\
\hline \multirow[t]{6}{*}{ Income } & Below 15000 & 4 & 2.6 \\
\hline & $15000-25000$ & 25 & 16.1 \\
\hline & $25000-35000$ & 27 & 17.4 \\
\hline & & 35 & 22.6 \\
\hline & $45000-55000$ & 29 & 18.7 \\
\hline & Above 55000 & 35 & 22.6 \\
\hline \multirow[t]{6}{*}{ Education } & Matriculation & 1 & .6 \\
\hline & Inter & 5 & 3.2 \\
\hline & Bachelor & 21 & 13.5 \\
\hline & Master & 70 & 45.2 \\
\hline & MS/M.phill & 40 & 25.8 \\
\hline & PHD & 18 & 11.6 \\
\hline
\end{tabular}




\section{Macrothink \\ International Journal of Human Resource Studies \\ ISSN 2162-3058 \\ 2014, Vol. 4, No. 2}

\subsection{Hypothesis Testing}

This segment of the research finally tests the model after satisfying the requirements of reliability and Validity. The Causal relationships of the independent variables were on the dependent variables.

\subsubsection{Working Condition and Employee Satisfaction}

According to the results of the research, the variable of working condition has a significant positive relationship with Employee Satisfaction. Specifically, this variable has a significant positive relationship with $(\mathrm{Beta}=.222)$ and $(\mathrm{p}<.003)$. That means the working Condition contributes more than $22 \%$ to Employee Satisfaction. Results of the current study validate the H1.

\subsubsection{Pay and Promotion and Employee Satisfaction}

The regression results of the research confirm the significant positive relationship between Pay and promotion and Employee Satisfaction with (Beta=.105) and ( $\mathrm{p}<.033)$. According to these results, Pay and promotion contributes more than $10 \%$ to Employee Satisfaction. This result of study validates $\mathrm{H} 2$.

\subsubsection{Job Safety and Security and Employee satisfaction}

Regression analysis of the Employee Satisfaction model depicts that there is a positive relationship between Job safety and security and Employee satisfaction with (Beta=.092) and $(\mathrm{p}<.048)$. The results suggest that Job Safety and Security contributes almost 9\% to Employee Satisfaction. The result of the study support H3.

\subsubsection{Training and Development and Employee Satisfaction}

The regression results of the research confirm the significant positive relationship between Training and Development and Employee Satisfaction with (Beta=.294) and ( $<<.000)$. According to these results, Training and Development contributes29\% more to Employee Satisfaction. The result of the study support H4.

\subsubsection{Employee Empowerment and Employee Satisfaction}

Regression results of the research represents the significant positive relationship between Employee Empowerment and Employee Satisfaction with (Beta=.219) and $(p<.003)$. According to these results, Employee Empowerment contributes 22\% more to Employee Satisfaction. The result of the study support H5.

\subsubsection{Working Condition and Job Performance}

Regression results of the research confirm the significant positive relationship between Working Condition and Job Performance with $($ Beta $=.101)$ and $(\mathrm{p}<.023)$. According to these results, Working Condition contributes $10 \%$ more to Job performance. The result of the study support H6. 


\section{Macrothink \\ International Journal of Human Resource Studies \\ ISSN 2162-3058 \\ 2014, Vol. 4, No. 2}

\subsubsection{Pay and promotion and Job Performance}

The regression results of the research confirm the no relationship between Pay and promotion and Job Performance with $($ Beta=.005) and $(\mathrm{p}<.953)$. According to these results, Pay and promotion contributes only $5 \%$ to Job Performance. This result of study validate $\mathrm{H} 7$

\subsubsection{Job Safety and Security and Job Performance}

Regression analysis of the Job Performance model shows that there is a significant positive relationship between Job Safety and Security and Job performance with (Beta=.141) and $(\mathrm{p}<.031)$. The results suggest that Job Safety and Security contributes almost $14 \%$ to Job Performance. The result of the study support H8.

\subsubsection{Training and Development and Job Performance}

The regression results of the study confirm no significant relationship between Training and Development and Job performance with $($ Beta $=.237)$ and $(\mathrm{p}<.006)$. According to these results, Training and Development contributes only $23 \%$ more to Job Performance. The result of the study support H9.

\subsubsection{Employee Empowerment and Job Performance}

The Regression results of the research confirm the strong positive relationship between Employee Empowerment and Job performance with (Beta=.252) and ( $\mathrm{p}<.003)$. According to these results, Employee Empowerment contributes 25\% more to Job performance. The result of the study support H10.

\subsubsection{Employee Satisfaction and Job Performance}

The regression outcomes of the research confirm the significant positive relationship between Employee Satisfaction and Job Performance with (Beta=.344) and ( $\mathrm{p}<.000)$. According to these results, Employee Satisfaction contributes 34\% more to Job Performance. The result of the study support H11.

\subsubsection{Employee Satisfaction and Turnover Intention}

The Regression results of the research confirm the negative relationship between Employee Satisfaction and Turnover Intention with $($ Beta=-.374) and $(\mathrm{p}<.000)$. The result of the study support H12. 
Regression Results

\begin{tabular}{|c|c|c|c|c|c|c|}
\hline Hypothesis & Model Variables & Estimates & S.E. & C.R. & $\mathrm{P}$ & Results \\
\hline H1 & ${ }_{\mathrm{ES}}^{\mathrm{WC}} \longrightarrow$ & .222 & .067 & 3.009 & .003 & Supported \\
\hline $\mathrm{H} 2$ & $\underset{\mathrm{ES}}{\mathrm{P} \& \mathrm{P} \longrightarrow}$ & .105 & .075 & 1.885 & .033 & Supported \\
\hline H3 & $\underset{\mathrm{ES}}{\mathrm{JS} \& S \mathrm{~S}}$ & .092 & .062 & 1.886 & .048 & Supported \\
\hline $\mathrm{H} 4$ & $\begin{array}{l}\mathrm{T} \& \mathrm{D} \longrightarrow \\
\mathrm{ES}\end{array}$ & .294 & .062 & 4.121 & .000 & Supported \\
\hline H5 & $\underset{\mathrm{ES}}{\mathrm{EE}} \longrightarrow$ & .219 & .075 & 3.032 & .003 & Supported \\
\hline H6 & ${ }_{\mathrm{JP}}^{\mathrm{WC}} \longrightarrow$ & .101 & .065 & 1.984 & .003 & Supported \\
\hline H7 & $\underset{\mathrm{JP}}{\mathrm{P} \& \mathrm{P} \longrightarrow}$ & .005 & .071 & -.059 & .023 & Supported \\
\hline H8 & $\underset{\mathrm{JP}}{\mathrm{JS} \& \mathrm{~S} \longrightarrow}$ & .141 & .059 & 1.845 & .953 & $\begin{array}{l}\text { Not } \\
\text { Supported }\end{array}$ \\
\hline H9 & $\underset{\mathrm{JP}}{\mathrm{T} \& \mathrm{D} \longrightarrow}$ & .237 & .061 & -2.807 & .031 & Supported \\
\hline H10 & $\mathrm{JP}^{\mathrm{EE}}$ & .252 & .073 & 3.018 & .006 & $\begin{array}{l}\text { Not } \\
\text { Supported }\end{array}$ \\
\hline H11 & $\mathrm{JP}^{\mathrm{ES}}$ & .344 & .077 & 3.728 & .003 & Supported \\
\hline H12 & $\underset{\mathrm{TI}}{\mathrm{ES}} \longrightarrow$ & -.374 & .092 & -4.995 & .000 & Supported \\
\hline
\end{tabular}




\section{Discussion}

The objective majorly associated with this research was to see the relationship between the antecedents of the study and the employee satisfaction and how deep is the impact of the antecedents on employee satisfaction. For this purpose the factors chosen for this study were Working conditions, pay and promotion, job safety and security, training and development and employee empowerment.

Woking condition was found to be the one most important factor impacting employee satisfaction in this research. Management could create work effectiveness by creating comfortable and advanced working conditions for the ease of employees to be able to work in an efficient and effective manner. The work places should be designed in such a manner that increases employee's productivity and adds to the health and welfare of employees. At one side good working conditions smooth communication and teamwork is enhanced in the presence of elegant work environment and at the other hand it definitely contributes in increasing the satisfaction level of employees. So in order to increase the satisfaction of employee`s and their job performance level organization should provide stretchy, modifiable and convenient workplaces.

Pay and promotion greatly affects the level of satisfaction of employees founded by this research. The organizations that pay their employees fairly according to the duties and responsibilities they perform on their job perceives a higher level of employee satisfaction as compared to the organization who don't bother about equity based pays.

Promotion should be awarded to the employee on just basis to enhance their motivation level to perform even better and satisfaction level is increase through fair and equitable pay and promotion system. Job performance has no significance relationship with the pay and promotion.

The research found that job performance and organizational commitment are negatively correlated with job insecurity. Job safety and security increases the loyalty and commitment level of employee with the organization as the employees are assure and confident about continuing their jobs so they perform more dedicatedly and whole heartedly for the betterment of their organization and they perceive a feeling of inner satisfaction. Now it has been proven from the current research that job safety and security contributes equally in enhancing the employee satisfaction level and ultimately increases the job performance of an individual in any organization.

Training is assumed as a useful tool for employees to perform their jobs according to the set required standards of the organization. If the training sessions are periodically arranged for employees for improving the skills required to perform the jobs it may help in better job performance and a feeling of satisfaction is derived out. So education about one`s job that means providing training to the individual enhances its satisfaction level and performance as well.

Training if at one side increases job satisfaction level it on the other side helps organization to reduce faulty works improves the productivity and reduces the turnover of the employees that 
means it touches the employee satisfaction level and job performance.

The satisfaction of employees is increased by the involvement of employees. Employees are able to perform their jobs independently without the interference of management with the help of employee empowerment. Employees contribute in making decision for the betterment of the organization and attaining goals by the help of employee empowerment. When the employees are given authority and power they feel satisfied and stronger inside. Empowerment feeling have a positive impact on job satisfaction. EmpoweringEmployees involve moving decision making to the lowest level possible in theorganization. Research specifies that employees should be encouraged to get together inthe meetings to discuss reports and measurements and policies and make decisions. Employee empowerment increases the satisfaction of employees and increases their job performance level.

The results of the study depict a significant positive relationship between the Employee satisfaction and Job performance. When the employees feel satisfied about their jobs their efforts towards their jobs also increases in the same way, the more they satisfied the harder and truly they work towards organizations benefits, means the performance level enhanced. So the Employee satisfaction is highly influential on Job Performance.

Another strong relation confirmed by this study is between the Employee Satisfaction and the turnover intentions. They both have negative strong relationship. As the satisfaction level of the employees increases the likelihood of switching or changing the organization decreases. Both the factors having inverse relationship, an increased turnover intention would be resulted as a low satisfaction level and an increased satisfaction would result in a low turnover intention.

\section{Limitations and Future Research}

This research has faced few limitations due to time and resources constraints. The first limitation following this research is that it has single source of data obtained through surveys on cross-sectional basis. Second is that only few antecedents are taken under observation to see the relationship between employee satisfaction and the antecedents. Another limitation is that the research was conducted in only one city (Bahawalpur) of Pakistan. Other than this the number of respondents of this research was less in number. There could be more respondents in number to make the research more effective. In future research more antecedents could be added to view the relationship between employee satisfaction and factors more accurately.

\section{References}

Lawler, E.E. (1990), High Involvement Management, Jossey-Bass, San Francisco, CA

Locke, E.A. (1976), “The nature and causes of job satisfaction”, in Dunnette, M.D. (Ed.),

Handbook of I/O Psychology, Rand-McNally, Chicago, IL.

Rainey, H.G. (1997), Understanding and Managing Public Organizations, 2nd ed., Jossey-Bass, San Francisco, CA. 


\section{Macrothink}

International Journal of Human Resource Studies ISSN 2162-3058 2014, Vol. 4, No. 2

Spector, P.E. (1997), Job Satisfaction: Application, Assessment, Causes, and Consequences, Sage, Thousand Oaks, CA.

Cranny, C.J., Smith, P.C. and Stone, E.F. (1992), Job Satisfaction: How People Feel about Their Jobs and How It Affects Their Performance, Lexington, New York, NY.

[6] Sweeney, A., Hohenshil, T. and Fortune, J. (2002), "Job satisfaction among employee assistance professionals", Journal of Employment Counselling, Vol. 39, pp. 52-60

Rice, R., McFarlin, D. and Bennett, D. (1989), "Standards of comparison and job satisfaction", Journal of Applied Psychology, Vol. 74, pp. 591-8.

Togia, A., Koustelios, A. and Tsigilis, N. (2004), "Job satisfaction among Greek academic librarians", Library \& Information Science Research, Vol. 26, pp. 373-83.

Porter, L.W. and Lawler, E.E. (1968), Managerial Attitudes and Performance, Irwin-Dorsey,Homewood, IL.

Hersey, P. and Blanchard, K.H. (1993), Leadership Style: Attitudes and Behaviors, Prentice Hall, Englewood Cliffs, NJ.

Le'vy-Garboua, L. and Montmarquette, C. (2004), "Reported job satisfaction: what does it mean?”, Journal of Socio-Economics, Vol. 33, pp. 135-51.

Sousa-Poza A (2000). Well-being at work. A cross-national analysis of the levels and determinants of job satisfaction. J. Socio-Econ., 29(6): 517-538.

Nanda R, Browne JJ (1977). Hours of work, job satisfaction and productivity. Public Productivity Rev., 2. (3): 46-56.

Meyer M (1999). Managing human resources development. An outcomes-based approach. Durban Butterworth Publishers (Pvt) Ltd.

Currall SC, Towler AJ, Judge, TA, Kohn, (2005). Pay satisfaction and organizational outcomes. Personnel Psychol., 58: 613-640.

Rai Sumita (2004). Motivational Theories and Incentives Approaches. IBM Management Review.

Herzberg F (1968). One more time. How do you motivate employees? Harv. Bus. Rev. 46. (1): 53-62.

Spector P (2008). Industrial and Organizational Psychology. Research and Practice, 5th ed., John Wiley \& Sons, New York, NY.

Reiner MD, Zhao J (1999). The determinants of job satisfaction among United States Air Force's security police. Rev. Public Personnel Adm., 19(3): 5-18.

Ellickson M, Logsdon K (2001), Determinants of job satisfaction of municipal government employees. State Local Gov. Rev., 33(3): 173- 84. 


\section{Macrothink}

International Journal of Human Resource Studies

ISSN 2162-3058

2014, Vol. 4, No. 2

Forsyth CJ, Copes JH (1994), Determinants of job satisfaction among police officers. Int. R. Modern Sociol. 24(1): 109-16.

Ceylan C (1998). Do professional women have lower job satisfaction than professional men? Lawyers as a case study. Sex Roles. 38(7\&8): 521-537.

De Troyer, M. (2000), “The hospital sector in Europe - introductory report", TUTBSALTSA Conference, Brussels, pp. 25-7.

Frye MB (2004). Equity-based compensation for employees. Firm performance and determinants. J. Finan. Res. 27(1): 31-54.

Nguyen A, Taylor J, Bradley S (2003). Relative Pay and Job Satisfaction. Some New Evidence, MPRA Paper No 1382. Dawson P (1987).Computer Technology and the Job of the First-line Supervisor New Technology. Work Empl., 2(1): 47-59.

Sokoya SK (2000). Personal Predictors of Job Satisfaction for the Public Sector Manager. Implications for Management Practice and Development in a Developing Economy. J. Business in Developing Nations, available at www.rh.edu/Ismt/jbdnv40.htm.

Wiens-Tuers, B.A., \& Hill, E.T. (2002). Do they bother? Employer training of temporary workers. Review of Social Economy, 60(4), 543-566.

Zobal C (1998). The ideal team compensation system - an overview: Part I. Team Perform. Manage., 4(5): 235- 249.

Chiu, C.-H., Amemiya, C., Dewar, K., Kim, C.-B., Ruddle, F.H., and Wagner, G.P. (2002) Molecular evolution of the HoxA cluster in the three major gnathostome lineages. Proc. Natl. Acad. Sci. USA 99(8): 5492-5497.

Moncarz E, Zhao J, Kay C (2009). An exploratory study of US lodging properties' organisational practices on employee turnover and retention, Int. J. Contemp. Hosp. Manage., 21(4): 437-458.

Cappelli, P. and Sherer, P. D. (1988). "Satisfaction, market wages \& labor relations: an airline study.” Industrial Relations, Vol. 27 No. 1, 56-73.

Clark, A. E., and Oswald, A. J. (1996). "Satisfaction and comparison income." Journal of Public Economics, Vol. 61, 359-381.

Hammermesh, D. S. (2001). "The changing distribution of job satisfaction." The Journal of Human Resources, Vol. 36 No. 1, 1-30.

Ashford, S, Lee, C\&Bobko, P. (1989). Content, causes, and consequences of job insecurity: A theory-based measure and substantive test. Acad. Manage. J., 32: 803-829.

Abegglen JC (1958). The Japanese Factory. Aspects of Its Social. Organization. Free Press. Glencoe. IL.

Bolt JF (1983). "Job security: its time has come, Harv. Bus. Rev., 61(6): 115- 123. 
Mooney M (1984). Let's use job security as a productivity builder. Personnel Adm., 29(1): $38-44$.

Rosow JM, Zager R (1985). The case for employment security. Across Board, 22: 34-41.

Morris T, Lydka H, O'Creevy MF (1993). Can commitment be managed? A longitudinal analysis of employee commitment and human resource policies. Hum. Res. Manage. J., 3(3): $21-42$.

Iverson RD (1996). Employee acceptance of organizational change. The role of organizational commitment. Int. J. Hum. Res. Manage., 7(1): 122-49.

Rosenblatt Z, Ruvio A (1996). A test of a multidimensional model of job insecurity. The case of Israeli teachers. J. Organ. Behav., 17: 587- 605.

Jun, M., Cai, S. and Shin, H. (2006), "TQM practice in maquiladora: antecedents of employee satisfaction and loyalty", Journal of Operations Management, Vol. 24, pp. 791-812.

Martensen, A. and Gronholdt, L. (2001), "Using employee satisfaction measurement to improve people management: an adaptation of Kano's quality types”, Total Quality Management, Vol. 2 Nos 7/8, pp. 949-57

Martensen, A. and Gronholdt, L. (2001), "Using employee satisfaction measurement to improve people management: an adaptation of Kano's quality types”, Total Quality Management, Vol. 2 Nos 7/8, pp. 949-57

Shields, M.A. and Wheatley, S. (2002), "Racial harassment, job satisfaction and intentions to quit: evidence from the British nursing profession", Economica, Vol. 69 No. 274, pp. 295-326.

Schmidt, S.W. (2007a), "The relationship between satisfaction and job training and overall job satisfaction", unpublished doctoral dissertation, University of Wisconsin, Milwaukee.

Landy, F.J. (Ed.) (1985), Psychology of Work Behaviour, IL Dorsey Press, Homewood, IL.

Schmidt, S.W. (2007b), "The relationship between satisfaction with work place training and over all job satisfaction”, Human Resource Development Quarterly, Vol. 18 No. 4, pp. 481-98

Georgellis, Y. and Lange, T. (2007), "Participation in continuous, on-the-job training and the impact on job satisfaction: longitudinal evidence from the German labour market", The International Journal of Human Resource Management, Vol. 18 No. 6, pp. 969-85.

Jones, M.K, Jones, R.J., Latreille, P.L. and Sloane, P.J. (2008), “Training, job satisfaction and workplace performance in Britain: evidence from WERS 2004”, IZA discussion papers 3677, Institute for the Study of Labor (IZA), Bonn.

Blum, R. and Kaplan, J.M. (2000), Network Professionals Job Satisfaction, Lucent Technologies network care, Chicago, IL.

Carless, S.A. (2004), "Does psychological empowerment mediate the relationship between psychological climate and job satisfaction?”, Journal of Business and Psychology, Vol. 18, pp. 
405-25.

Haas, M.R. (2010), "The double-edged swords of autonomy and external knowledge: analyzing team effectiveness in a multinational organization", The Academy of Management Journal, Vol. 53, pp. 989-1008.

Hales, C. and Klidas, A. (1998), "Empowerment in five-star hotels: choice, voice or rhetoric?", International

Journal of Contemporary Hospitality Management, Vol. 10 No. 3, pp. 88-95.

Conger, J.A. and Kanungo, R.N. (1988), "The empowerment process: integrating theory and practice", Academy of Management Review, Vol. 13 No. 3, pp. 471-82.

Spreitzer, G.M., Kızılos, M.A. and Nason, S.W. (1997), “A dimensional analysis of the relationship between psychological empowerment and effectiveness, satisfaction and strain", Journal of Management, Vol. 23 No. 5, pp. 679-704.

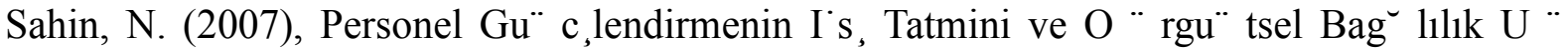
zerine Etkisi: Do“ rt ve Bes, Yıldızlı Otel I’s, letmelerinde Bir Aras,tırma, Dokuz Eylu“1 U“ niversitesi Sosyal Bilimler Enstitu"su", I'zmir

Wang, G. and Lee, P.D. (2009), "Psychological empowerment and job satisfaction: an analysis of interactive effects", Group Organization Management, Vol. 34 No. 3, pp. 271-96.

Yoon, M.H., Beatty, S.E. and Suh, V. (2001), "The effect of work climate on critical employee andn customer outcomes: an employee-level analysis", International Journal of Service Industry Management, Vol. 12 No. 5, pp. 500-21.

Babin, B.J. and Boles, J.S. (1996), "The effect of perceived co-worker involvement and supervisor support on service provider role stress, performance and job satisfaction”, Journal of Retailing, Vol. 72 No. 1, pp. 57-75.

Mobley, W.H. (1977), "Intermediate linkages in the relationship between job satisfaction and employee turnover”, Journal of Applied Psychology, Vol. 62, pp. 237-40.

Tett, R.P. and Meyer, J.P. (1993), "Job satisfaction, organizational commitment, turnover intention, and turnover: path analysis based on meta-analytic findings", Personnel Psychology, Vol. 46, pp. 259-93.

Muchinsky, P. M., \& Morrow, P. C. (1980). A multidisciplinary model of voluntary employee turnover. Journal of Vocational Behavior, 17, 263-290.

Trevor, C. O. (2001). Interactive effects among actual ease of movement determinants and job satisfaction in the prediction of voluntary turnover. Academy of ManagementJournal, 44, 621-638.

Boshoff, C., \& Allen, J. (2000). The influence of selected antecedents on frontline staff's perceptions of service recovery performance. International Journal of Service Industry Management, 11(1), 63-90. 
Martin, T. N. (1979). A contextual model of employee turnover intentions. Academy of Management Journal, 22(2), 313-324.

Viator, R. E. (2001). The association of formal and informal public accounting mentoring with role stress and related job outcomes. Accounting, Organizations and Society, 26, 73-93.

Gneezy U, Rustichini A (2000). Pay enough or don't pay at all. Q. J. Econ., 115: 791-810.

Gardner DG, Dyne LV, Pierce JL (2004). The effects of pay level on organization based self-esteem and performance. A field study. J. Occup. Organ. Psychol., 77: 307-322.

Ashford, S, Lee, C\&Bobko, P. (1989). Content, causes, and consequences of job insecurity: A theory-based measure andsubstantive test. Acad. Manage. J., 32: 803-829.

Davy J, Kinicki A, Scheck C (1991). Developing and testing a model of survivor responses to layoffs. J. Vocat. Behav. 38: 302-317

Bhatti, K.K. and Qureshi, T.M. (2007), "Impact of employee participation on job satisfaction, employee commitment and employee productivity", International Review of Business Research Papers, Vol. 3 No. 2.

Ampofo-Boateng, K., Merican, W.R.A., Jamil, A. and Wiegand, B. (1997), "Employees' adaptation", technology management - the key to global leadership", PICMET'97: Portland International Conference on Management and Technology, Portland, 27-31 July, pp. 987-9.

Younas, M., Rizwan, M., Khan, S., Majeed, Z., Khalid, S. \& Anjum, S. (2013) The Impact of Some Specific Factors on Employee Satisfaction: An Empirical Study from Pakistan. Journal of Basic and Applied Scientific Research, 3(12), 323-334

Rizwan, M., Shahzad, N., Sheikh, Q., Batool, S., Riaz, M. \& Saddique, S. (2013) Variables that Have an Impact on Employee Satisfaction And Turnover Intention, International Journal of Research in Commerce, Economics and Management, 3(3), 131-138

Seibert, S.E., Silver, S.R. and Randolph, W.A. (2004), "Taking empowerment to the next level: a multiple-level model of empowerment, performance, and satisfaction", Academy of Management Journal, Vol. 47 No. 3, pp. 332-49.

Snipes, R.L., Oswald, S.L., La Tourc, M. and Armenakis, A.A. (2005), "The effects of specific job satisfaction facets on customer perceptions of service quality: an employee-level analysis", Journal of Business Research, Vol. 58, pp. 1330-9.

Chao, G.T., O’Leary-Kelly, A.M., Wolf, S., Klein, H.J. and Gardner, P.D. (1994), "Organizational socialization: its content and consequences", Journal of Applied Psychology, Vol. 79, pp. 730-43.

Velthouse, B.A. (1990), "Creativity and empowerment: a complementary relationship", Review of Business, Vol. 12, Fall, pp. 13-18.

Rizwan, M., Jaskani, J. H., Ameen, H., Hussain, S., Farooq, R. U., and Omair, M. (2013). Antecedents of Employee Satisfaction and it's impact on Job Turnover, International journal 


\section{Macrothink \\ International Journal of Human Resource Studies \\ ISSN 2162-3058 2014, Vol. 4, No. 2}

of Management Sciences and Business Research, 2(1), 55-64

Kumar (2005:179) motivates that purposive sampling is extremely usefulwhen constructing a historical reality, describing a phenomenon ordeveloping something about which only a little is known.

Creswell, J.W. (1994) Research Design: Qualitative and Quantitative Approaches.Thousand Oaks; London: SAGE.

Zikmund, W. G. (1997). Business Research Method. Fifth ed. The Drydenpress, Harcourt Brace College Publishers, Orlando, Florida. 